\title{
PROPOSALS FOR THE DIGITAL MARKETS ACT AND DIGITAL SERVICES ACT - BROADER CONSIDERATIONS IN CONTEXT OF ONLINE PLATFORMS*
}

\author{
Simona Rudohradská, PhD Candidate \\ P. J. Šafárik University in Košice, Faculty of Law \\ Kováčska 26, 04001 Košice, Slovakia \\ simona.rudohradska@student.upjs.sk
}

\author{
Diana Treščáková, PhD, Teaching and Research Assistant \\ P. J. Šafárik University in Košice, Faculty of Law \\ Kováčska 26, 04001 Košice, Slovakia \\ diana.trescakova@upjs.sk
}

\begin{abstract}
Proposals for a Regulation on a Single Market For Digital Services (Digital Services Act) and Regulation on contestable and fair markets in the digital sector (Digital Markets Atc) of 15th of December, 2020 were long-avaited tools, through which, in the field of digital services, a higher degree of legal certainty for the consumer should be ensured and the functional responsibility regime of online platforms should be secured, in direct proportion. Submitted proposals preceded open public consultation of interested stakeholders, including the general public, academics, digital companies and other businesses, associations, civil society public authorities, and trade unions. The need to adopt adequate legislation in line with rapid technological development also stemmed from the fact that the E-commerce Directive was adopted in 2000 and has so far been considered as the main legal framework governing the issue of digital platforms, but it is also necessary to add that the regulation of online platforms has been mainly left to the Member States. As much of the activity has shifted to the online enviroment, digital platforms are playing an increasingly important role in our lives. The purpose of this paper is to analyze the relevant provisions of the proposal in the context of competition rules and also in view of the increased use of online platforms due to the global crisis. The content of the article will also contain a brief comparison with the current legal situation with reference to the practical implications that await us with the adoption of the new legislation.
\end{abstract}

Keywords: Digital Services Act, Digital Markets Act, competition law, online platforms

This work was supported by the Slovak Research and Development Agency uder the Contract no. APVV-19-0424 and APVV-17-0561 Human-legal and ethical aspects of cyber security. 


\section{INTRODUCTION}

Digital technologies are now an integral part of our lives. Their use on a daily basis has been exacerbated by the current global pandemic situation, caused by the spread of COVID-19 virus. Practically, from day to day we have moved most of our activities to the online space, not excluding work duties, purchasing essential needs, communicating with close persons or handling administrative matters. With regard to the mentioned transfer of our activities to the online environment, as it showed up, there are many barriers and opened legal issues that are undoubtedly related to acting in the online space. Unambiguously, one of the legal issues related to operating in the online space is question conjoint with protection of personal data, protection of the consumer, blocking of acces to certain content (whether for commercial or legal reasons), liability regime for content posted online, but also a wide range of aspects related to the operation of digital online platforms.

When it comes to the category of digital, online or collaborative platforms - as they tend to be synonymously referred to, these are the subject of expert discussions in terms of several aspects. Above all, it is necessary to emphasize the responsibility of the platforms, in relation to the provision of these services, their market position, their relation to the standard service providers, as well as the position of the individual platforms to each other.

Equally resonant is unfair competition of digital platforms in relation to business conditions or platform practices, or even their anti-competitive behavior. One of the matter discussed in this regard is the general consideration of which entities are actually online platforms. Following this question, another one arises as what parameters must these subject meet in order to perceive them as online platforms and what consequences follow from these position.

In relation to online platforms and the institute of competition, both public and private aspects resonate. When we mean private law aspects, in particular, these will be related to the business conditions of individual platforms, on the one hand, in relation to customers, but also on the other hand, business in relation to persons who provide these services through these platforms.

The question also remains whether the platform itself provides the service, or is merely the sole intermediary between the direct service provider and the customer as the final recipient of the service. Online platforms are generally defined as exclusive intermediaries, who stand between the direct service provider and the customer as the addressee of the service. ${ }^{1}$ Finally, in the European Agenda for the

De Franceschi, A., Uber Spain and the "Identity Crisis" of Online Platforms, Journal of European Consumer and Market Law, 2018, Vol. 7, Issue 1, pp. 1-4, [https://kluwerlawonline.com/journalarticle/Jour- 
Collaborative Economy, the European Commission stated that whether the service is provided by the platform or is merely an intermediary needs to be examined on a case-by-case basis (2016). ${ }^{2}$

In assessing the above-mentioned points and finding alternatives from the basis for their regulation, we consider two aspects to be key -thus which entities can be considered as online digital platforms and what is the current situation of regulation of digital platforms in the context of competition. In particular, the two proposals for the regulations published at the end of last year are of considerable importance in this regard - proposal for the regulation of Digital Services Act and proposal for the regulation of Digital Markets Act.

The aim of this paper will be not to answer all the questions raised in connection with digital platforms and collaborative economy, but just to analyze the legislation de lege lata in the context of digital platforms and competition. We will also try to point out to the subject-matter of legislation which is currently in the process of being adopted, especially with regard to the European legislators.

\section{PLATFORMS - CONSIDERATIONS FOR LEGAL DEFINITIONS}

We use the terms such as online platform, digital platform or collaborative platform regularly, in various meanings. However in standard conversation, we usually attribute them a different signifacance as when we use these terms in a legal context. In these intentions, we also meet with a conceptual definition, more clearly, with differentiation of the platforms as bilateral platforms, possibly multilateral platforms. It will therefore be important to differentiate for what purpose the term needs to be defined, resp. what specific question we are looking for an answer to.

With respect to the mentioned, we point out to the division of online platforms, which is presented by prof. Bejček, while noting, that it is more accurate to use the term platform, as the notion market, as it makes it possible to distinguish between goods and services according to the way in which they are offered and subsequently traded with them. ${ }^{3}$ As bilateral platforms are marked that onest hat connect the seller and the consumer, trilateral platforms as those, which restrain consumers, con-

nal+of+European+Consumer+and+Market+Law/7.1/EuCML2018001], Accessed 11 January 2021.

2 A European agenda for the collaborative economy, $\operatorname{COM}(2016) 356$ final, p. 8, available at: [https:// eur-lex.europa.eu/legal-content/EN/TXT/PDF/?uri=CELEX:52016DC0356\&from=EN], Accessed 11 January 2021.

3 Bejček, J., On the Impact of Digitalization of Economy and Competition Law - a Storm in a Teacup?, in: Suchoža, J.; Husár, J.; Hučková, R. (eds.), Právo, obchod, ekonomika VII., Košice: Univerzita P.J.Šafárika v Košiciach, 2017, p. 27. 
tent providers and advertisers and multilateral platforms (cites credit cards as an example).

According to the criterion of target persons, referring to OECD sources, prof. Bejček divides platforms into connecting peers (P2P), traders with traders (B2B), or consumer with traders (B2C). According to the functionality, we can divide platforms to the so-called search engines (GoogleSearch, TripAdvisor), electronic online markets (Amazon, Booking.com, eBay), common economic networks in a shared or interconnecting economy (Uber, Airbnb), social networks (LinedIn, Instagram, Facebook), or app stores (Apple 's App Store, Google Play). ${ }^{4}$ In view of the above mentioned, we can state that the platforms can be divided from different perspectives.

In this regard, we draw attention to the characteristics of the collaborative platform, as part of a shared economy, which is just one of the different types of platforms used online. The European Commission has made a clearer definition of the terms collaborative economy and collaborative platform in the European Agenda for the Collaborative Economy. European Commission characterizes the collaborative economy as well as the collaborative platforms as follows :

„The collaborative economy involves three categories of actors:

(i) service providers who share assets, resources, time and/or skills - these can be private individuals offering services on an occasional basis ('peers') or service providers acting in their professional capacity ("professional services providers");

(ii) users of these; and

(iii) intermediaries that connect — via an online platform — providers with users and that facilitate transactions between them ('collaborative platforms'). Collaborative economy transactions generally do not involve a change of ownership and can be carried out for profit or not-for-profit." ${ }^{\text {" }}$

In these intentions we also point out the idea presented by doc. Kalesná and dr. Patakyová, that even in the absence of a universal definition of online platforms, it is necessary to distinguish between the right shared economy, offering exchanges at the local level, from profit-oriented global trade, the so-called uberization of the economy. ${ }^{6}$ The

\section{Ibid.}

A European agenda for the collaborative economy $\{\operatorname{SWD}(2016) 184$ final\}, $\operatorname{COM}(2016) 356$ final, p. 3. Kálesná. K.; Patakyová T., Digitálne platformy: sútažné právo verzus regulácia ex ante, Právny obzor, Vol. 104, No. 1, 2021, p. 26-38. 
notion -uberization or uberification ${ }^{7}$ - can be characterized as a process or the act of changing the market for a service by introducing a different way of buying or using it, especially using mobile technology. ${ }^{8}$

In the context of online platforms is also frequently mentioned notion- information society services defined as ,any service normally provided for remuneration, at a distance, by electronic means and at the individual request of a recipient of services." "Therein the well known in this regard is the judgment of the Court of Justice of the European Union in the case Asociación Profesional Élite Taxi against Uber Systems Spain SL, C-434/15, establishing that the services provided by Uber are not information society services, but they are inextricably linked to transport services. ${ }^{10}$

So far, the regulation of collaborative platforms has been left largely to individual Member States and documents issued by the European Union in the field in this question were rather non-binding or recommendatory in nature. ${ }^{11}$ Finally, the Court of Justice of the European Union also reflects to this fact in cited judgment. That classification is indeed confirmed by the case-law of the Court, according to which the concept of 'services in the field of transport' includes not only transport services in themselves but also any service inherently linked to any physical act of moving persons or goods from one place to another by means of transport. ${ }^{12}$

Lastly, the fact that the regulation of the conditions under which platforms may provides their services is left to the Member States is also emphasized by the Court of Justice. „It follows that, as EU law currently stands, it is for the Member States to regulate the conditions under which intermediation services such as that at issue in the main proceedings are to be provided in conformity with the general rules of the FEU Treaty. ${ }^{13}$ The Court of Justice uses the term „services such as

$7 \quad$ As it is used to be synonymously referred to, see for example Daidj, N., "Uberization (or uberification) of the economy," Post-Print hal-02374117, HAL., 2017, DOI: 10.4018/978-1-5225-2255-3.ch204.

8 Cambridge dictionary, available at: [https://dictionary.cambridge.org/dictionary/english/uberization], Accessed 08 April 2021.

9 Directive (eu) 2015/1535 of the European Parliament and of the Council of 9 September 2015 laying down a procedure for the provision of information in the field of technical regulations and of rules on Information Society services (codification), Art. 1 (1), b.

10 Judgment of 20 December 2017, Asociación Profesional Elite Taxi, C-434/15, ECLI:EU:C:2017:981.

11 For example De Franceschi, op. cit., note 1, p. 4; Busch, C.; Schulte-Nölke, H.; Wiewiórowska-Domagalska, S.; Zoll, F., The Rise of the Platform Economy: A New Challenge for EU Consumer Law?, Journal of European Consumer and Market Law Vol. 3, Issue 1, 2016, p. 4.

12 Judgment of 20 December 2017, Asociación Profesional Elite Taxi, C-434/15, ECLI:EU:C:2017:981, point 41 .

13 Judgment of 20 December 2017, Asociación Profesional Elite Taxi, C-434/15, ECLI:EU:C:2017:981, point 47 . 
that", which seems to mean, in particular, collaborative platforms in the field of transport. Subsuming a platform under definition means its exclusion from the concept of information society services, and all the benefits flowing from them.

\section{THE CURRENT STATE OF REGULATION OF DIGITAL PLATFORMS}

As it is stated several times in this paper, regulation of online platforms has been generally left to the Member States. In relation to online platforms and online services, the Directive 2000/31/EC of the European Parliament and of the Council of 8 June 2000 on certain legal aspects of information society services, in particular electronic commerce, in the Internal Market (Directive on electronic commerce) has been referred as the basic regulatory legal framework. With reference to fact, that the E-commerce directive was adopted in 2000, it is evident that the current era of digitization, brings necessity for new legal regulation to sufficiently reflect the dynamics and development in this area.

When we focus on the questions of competition associated with the platforms, we run into a problem. With reference to Article 1 para. 5 letter b) E-commerce Directive which stipulates that „This Directive shall not apply to questions relating to agreements or practices governed by cartel law", the wording of the E-commerce directive itself precludes its application or effect on competition rules. Until now, therefore, legislation following platforms and competition issues has been governed by primary law starting with Article 101 of the Treaty on the Functioning of the EU, and the relevant secondary law. Secondary law completing the legal framework of competition legislation is made up primarily of regulations.

It is also important to note that currently in relation to online platforms and intermediary services, we also have regulation Regulation 2019/1150 of the European parliament and of the Council of 20 June 2019 on promoting fairness and transparency for business users of online intermediation services. This Regulation is, in essence, the first legal act to regulate specific aspects related to online platforms. This regulation can be referred to as business to business regulation (B2B), as its role is to adjust fair and transparent terms and conditions for business user, as they are defined in the Article 2 para. 1 of this Regulation. With the regard to subject matter of the regulation we can state that this legislative act is predominantly of a private law nature. Other key question, which is closely related to adjustment of digital platforms is ranking, whereas Article 5 of this Regulation sets up conditions under which main parameters determining ranking should be managed. 
Despite the fact that the area of online markets has certain specifics compared to standard markets, anti-competitive practices were standardly sanctioned by the application of the provisions of the Treaty of Functioning of the European Union.

Application of the „case by case“ principle to collaborative platforms (mentioned by the Commission) has to some extent been demonstrated in the case law of the Court of Justice. We point to the case Star Taxi App, C-62/19, while at first glance it might seem, that the services provided by Star Taxi App SRL will be assessed in the same way as services provided by Uber, but in this case the Court of Justice decided that an ,intermediary service consisting of connecting, for a fee, a smartphone application to persons wishing to travel within the city and drivers of authorized taxi services, the provider of which has entered into service contracts with those drivers for consideration of a monthly fee. subscription, but does not send them orders, does not set fares or ensure payment from these persons, who pay it directly to the taxi driver, and, in addition, does not control the quality of the vehicles and their drivers or the behavior of these drivers, is a "information society service" ..$^{14} 15$

\section{OBJECTIVES AND INTENTS OF THE SUBMITTED PROPOSALS OF DIGITAL SERVICES ACT AND DIGITAL MARKETS ACT}

\subsection{In general to both proposals}

The prediction of new legislation in the digital field was indicated by the second priority of the current composition of the European Commission - Europe fit for the digital age. As it is stated in the introduction of this priority „Europe must now strengthen its digital sovereignty and set standards, rather than following those of others - with a clear focus on data, technology, and infrastructure. "16 From initiate wording is clear, as well as from many other documents of the European Union, that the European Union wants to be as legally prepared as possible for the digital age which has already begun, but its real contours will not be fully apparent until the coming years.

Online space contains certain specifics, which we do not recognize in the offline environment. These specifics of the online environment can create legal uncer-

\footnotetext{
$14 \quad$ Unofficial translation by the authors.

15 Judgment of 3 December 2020, Star Taxi App, C-62/19, ECLI:EU:C:2020:980.

16 A Europe fit for the digital age. Empowering people with a new generation of technologies, [https:// ec.europa.eu/info/strategy/priorities-2019-2024/europe-fit-digital-age_en], Accessed 05 April 2021.
} 
tainty in many ways, especially with regard to the fact that when concluding virtual contracts we do not have the possibility of sufficient verification of the person standing on the other side. The issues of online security and, consequently, the security of online shopping have often been questioned, as unfortunately various fraudulent practices are still taking place today. However, the matter of online shopping security, as well as, for example, securing payments for goods purchased online, is extremely extensive and with the reagrd of the intentions of this article, we will not address it in more detail.

Following the above mentioned, it is necessary to draw attention to those practices which customers do not even need to be aware of at first and will only result from the observation of the relevant markets in which unfair practices apply. As set out in the explanatory memorandum of the Proposal of Digital Markets Act, from examination of the competent authorities at European Union level, several conflicting practices have been observed with unsatisfactory results in relation to the consumer or to the market itself: „unfair practices and lack of contestability lead to inefficient outcomes in the digital sector in terms of higher prices, lower quality, as well as less choice and innovation to the detriment of European consumers. Addressing these problems is of utmost importance in view of the size of the digital economy (estimated at between $4.5 \%$ to $15.5 \%$ of global GDP in 2019 with a growing trend) and the important role of online platforms in digital markets with its societal and economic implications. " ${ }^{17}$

The European Union has an interest in business and trade, in particular in securing a high degree of harmonization of Member States' legislation. This is undoubtedly related to the institute of the internal market. The legal basis of the internal market is to be found in primary law, namely in Article 4 para. 2 letter (a) and Articles 26, 27, 114 and 115 of the Treaty on the Functioning of the European Union. The aim of the common market created by the Treaty of Rome in 1958 was to remove barriers to trade between Member States in order to increase economic prosperity and contribute to the "ever closer unification of the peoples of Europe". ${ }^{18}$ This intention is also reflected in the current priorities of the European Commission, but at present the main obstacles are the obstacles appearing in the online environment. Mentioning online content, barriers or obstacles, it is necessary to point out, for example, to the European Union's initiatives in the field of

17 Proposal for a Regulation of the European Parliament and of the Council on contestable and fair markets in the digital sector (Digital Markets Act), COM(2020) 842 final 2020/0374 (COD), p. 1.

18 Vnútorný trh, Všeobecné zásady, available at: [https://www.europarl.europa.eu/factsheets/sk/sheet/33/ vnutorny-trh-vseobecne-zasady], Accessed 07 April 2021. 
removing geographical blocking (thus geoblocking), in order to maintain equal access to online services and goods for all citizens of the European Union.

The current state and the latest changes in the field of restructuring and crossborder conversion were processed in an interesting way by the author's team Dolný and Mrázová in contribution Recent Developments in European Company Law: Harmonisation of Restructuring and Cross-border Conversion. ${ }^{19}$ Efforts for a high degree of harmonization therefore do not exclude the area of online platforms either. Following the initial publication of the current Commission's priorities, it was clear that it was planning significant legislative changes in relation to online platforms. The term Digital Services Act was first used, and subsequently did the contours of the Digital Markets Act see the light of day.

The main objective of the presented legislative initiatives is to create a safer digital space in which the fundamental rights of all users of digital services are protected and to establish a level playing field to foster innovation, growth, and competitiveness, both in the European Single Market and globally. ${ }^{20}$ In the following two subchapters, we will try to specify the main intentions of the proposals.

\subsection{Proposal of Digital Services Act}

In general the main aims of the proposal of regulation Digital Services Act are presented as to better protect consumers and their fundamental rights online, to create a framework for high transparency and clear accountability of online platforms and to foster innovation, growth and competitiveness in the single market. ${ }^{21}$

If we look directly at the wording of the proposal of the regulation DSA, in Article 1 (the subject matter and scope) is defined that „This Regulation lays down harmonised rules on the provision of intermediary services in the internal market. In particular, it establishes:

(a) a framework for the conditional exemption from liability of providers of intermediary services;

19 Dolný, J.; Mrázová, Ž., Recent Developments in European Company Law: Harmonisation... of Restructuring and Cross-border Conversion, in: EVOLUTION OF PRIVATE LAW - NEW CHALLENGES , Publisher Instytut Prawa Gospodarczego Sp. z o.o., 2020, p. 63-71

20 Shaping Europe's digital future, POLICY, The Digital Services Act package, available at: [https:// ec.europa.eu/digital-single-market/en/digital-services-act-package], Accessed 05 April 2021.

21 The Digital Services Act: ensuring a safe and accountable online, available at: [environmenthttps:// ec.europa.eu/info/strategy/priorities-2019-2024/europe-fit-digital-age/digital-services-act-ensuring-safe-and-accountable-online-environment_sk], Accessed 30 April 2021. 
(b) rules on specific due diligence obligations tailored to certain specific categories of providers of intermediary services;

(c) rules on the implementation and enforcement of this Regulation, including as regards the cooperation of and coordination between the competent authorities."

The regulation itself sets its aim in Article 1 para. 2, as to:

„(a)contribute to the proper functioning of the internal market for intermediary services;

(b) set out uniform rules for a safe, predictable and trusted online environment, where fundamental rights enshrined in the Charter are effectively protected."

In relation to legislation which has hitherto been perceived as the basic regulatory framework, its scope is defined in the proposal of the regulation in Article 1 (5) (a). a) „This Regulation is without prejudice to the rules laid down by the Directive 2000/31/EC. " However, final provisions of proposal for a regulation DSA (Article 71 para. 1) declare that „Articles 12 to 15 of Directive 2000/31/EC shall be deleted." Mentioned articles of E-commerce Directive formed the basis of the legal framework for the liability of online platforms. Liability regim is comprehensively elaborated in the wording of the submitted preposol for a regulation DSA.

Aspects related to illegal content and liability for such content were considerably discussed. Liability regime of online platforms in conditions of the existing regulation was valuable processed in contribution by Rózenfeldová and Sokol. ${ }^{22}$ Answer to the question of the liability of platforms for the content that is published by them is due to the wording of the proposal for regulation DSA governed in Article 3, 4, 5 and 7 of the Proposal of DSA Regulation. In this connection, it is important to emphasis wording of the Article 7, which provides that: „No general obligation to monitor the information which providers of intermediary services transmit or store, nor actively to seek facts or circumstances indicating illegal activity shall be imposed on those providers."

The proposal of the DSA regulation addresses, in particular, the liability issues of intermediary platforms and sets out a number of new obligations arising from their position. The proposal for a regulation also introduces new institutes and mechanisms concerning online platforms. The adjusted scope of obligations is relatively wide and goes beyond the scope of this contribution. Meredith Broadbent in contribution The Digital Services Act, the Digital Markets Act, and the New

22 Rózenfeldová, L.; Sokol, P. Liability regime of online platforms new approaches and perspectives, in: Petrašević, T.; Duić, D.; Novokmet, A. (eds.), EU and Comparative Law Issues and Challenges Series (ECLIC), Vol. 3, 2019, p. 871. 
Competition Tool, mentiones that „companies and stakeholders have commented extensively on both Inception Impact Assessments. Regarding the DSA section, supporters note its potential to create legal certainty and deepen the European internal market while making liability and consumer-protection requirements more robust. Other voices have raised concerns over where the burden of liability and safety will fall and worry that illegal content would migrate to smaller, less regulated platforms. ${ }^{23}$

\subsection{Proposal of Digital Markets Act}

Some large online platforms act as "gatekeepers" in digital markets. The Digital Markets Act aims to ensure that these platforms behave in a fair way online. Together with the Digital Services Act, the Digital Markets Act is one of the centrepieces of the European digital strategy. ${ }^{24}$ Concept of Digital Markets Act is relatively different from the concept of Digital Services Act. The mentioned determinant of difference is primarily the introduction of the new notion - „gatekeep$\mathrm{er}^{\text {" }}$ - in the field of online enviroment for the purposes of applying the Regulation. This term has not yet been legally defined, whereas the submitted proposal for a regulation DMA clarified its contours. For a category of gatekeepers (characterized by both qualitative and quantitative criteria) are set completely new rules, which has not yet been contained in any legislation.

In contrast with proposal for a regulation DSA, proposal for a regulation DMA determine its subject-matter and scope in Article 1 as follow: „This Regulation lays down harmonised rules ensuring contestable and fair markets in the digital sector across the Union where gatekeepers are present. "With regard to this demarcation, we can state that the legislation in question will regulate primarily the public law aspects of online platforms.

DMA regulation is frequently reffered to as new competition tool. As we mentioned above, the digital environment carries with it certain specifics that we do not recognize in the offline space. In present we distinguish several platforms that have a really significant market position. Until now, the practices of these platforms have been penalized by standard competition law institutes although when

23 Broadbent M., The Digital Services Act, the Digital Markets Act, and the New Competition Tool, Center for strategic and internarional studies, November 20 2021,p. 8, available at: [https://www. csis.org/analysis/digital-services-act-digital-markets-act-and-new-competition-tool], Accessed 30 April 2021.

24 The Digital Markets Act: ensuring fair and open digital markets, [https://ec.europa.eu/info/strategy/ priorities-2019-2024/europe-fit-digital-age/digital-markets-act-ensuring-fair-and-open-digital-markets_en], Accessed 05 April 2021. 
the case showed certain digital specifics (such as use of personal data). This fundamental legal framework was, of course, Articles 101 and 102 of the Treaty on the Functioning of the European Union.

Obligations for gatekeepers are summarized in Article 5 and 6 . As their content is relatively extensive, we point out, for example to the requirement resulting from the dual role of gatekeeper. It is the case when gatekeeper is the core platform services provider but also provides the services by this core platform just like a commercial user. This position is mainly related to the obligations set out in Article 6 para. 1 d.) (among others).

\section{CONCLUSION}

Submitted proposals for Digital Sevices Act and Digital Markets Act can be considered as desirable. Given the significant position of digital platforms in the market and an exponential increase in their market power, it can be expected that in the coming period their position will only be strengthened. In view of these facts it is necessary to guarantee consumers a high degree of legal certainty, but also to ensure a clear catalog of rules for online platforms to follow. Despite the fragmentation of opinion whether there is a real need to regulate digital platforms, for example in competition matters beyond the current legislation, we insist on the idea, that if the legislation as DSA and DMA has not been adopted at European Union level, it could cause that Member States would gradually adopt national legislation on their own initiative which could ultimately result in different approaches to online platforms. For this reason, it is necessary to adapt the legislation to the business models of the 21st century and enable them to act on the market for the benefit of the consumer, however, with a guarantee of a high degree of protection of its interests. Nor can the protection of competitors be overlooked, for example in the light of the context of competition.

\section{REFERENCES}

\section{BOOKS AND ARTICLES}

1. Bejček, J., On the Impact of Digitalization of Economy and Competition Law - a Storm in a Teacup ?, in: Suchoža, J.; Husár, J.; Hučková, R. (eds.), Právo, obchod, ekonomika VIII., p. 23-42 Košice: Univerzita P.J.Šafárika v Košiciach, 2018

2. Busch, C.; Schulte-Nölke, H.; Wiewiórowska-Domagalska, S.; Zoll, F., The Rise of the Platform Economy: A New Challenge for EU Consumer Law?, Journal of European Consumer and Market Law Vol. 3, Issue 1, 2016, p. 3-10

3. Daidj, N., Uberization (or uberification) of the economy, Post-Print hal-02374117, 2017 HAL., pp. 2345-2355 
4. De Franceschi, A., Uber Spain and the "Identity Crisis" of Online Platforms, Journal of European Consumer and Market Law, 2018, Vol. 7, Issue 1, pp., 1-4, [https://kluwerlawonline.com/journalarticle/Journal+of+European+Consumer+and+Market+Law/7.1/EuCML2018001], Accessed 11 January 2021

5. Dolný, J.; Mrázová, Ž., Recent Developments in European Company Law: Harmonisation... of Restructuring and Cross-border Conversion, in: EVOLUTION OF PRIVATE LAW - NEW CHALLENGES , Publisher Instytut Prawa Gospodarczego Sp. z o.o., 2020., p. 63-71

6. Kálesná. K.; Patakyová T., Digitálne platformy: sútažné právo verzus regulácia ex ante, Právny obzor, Vol. 104, No. 1, 2021, p. 26-38

\section{EU LAW}

1. A European agenda for the collaborative economy $\{\operatorname{SWD}(2016) 184$ final $\}, \operatorname{COM}(2016)$ 356 final

2. Directive 2015/1535 of the European Parliament and of the Council of 9 September 2015 laying down a procedure for the provision of information in the field of technical regulations and of rules on Information Society services (codification)

3. Proposal for a Regulation of the European Parliament and of the Council on contestable and fair markets in the digital sector (Digital Markets Act), $\operatorname{COM(2020)~} 842$ final 2020/0374 (COD)

4. Regulation of the European parliament and of the Council on contestable and fair markets in the digital sector (Digital Markets Act)COM(2020) 842 final, 2020/0374(COD)

5. Regulation of the European Parliament and of the Council on contestable and fair markets in the digital sector (Digital Markets Act), COM(2020) 842 final 2020/0374 (COD)

\section{COURT OF JUSTICE OF THE EUROPEAN UNION}

1. Case C-434/15 Asociación Profesional Elite Taxiv Uber Systems Spain, ECLI:EU:C:2017:981

2. Case C-62/19 Star Taxi App SRL v Unitatea Administrativ Teritorială Municipiul Bucureşti prin Primar General and Consiliul General al Municipiului Bucureşti ECLI:EU:C:2020:980

\section{WEBSITE REFERENCES}

1. A Europe fit for the digital age. Empowering people with a new generation of technologies, [https://ec.europa.eu/info/strategy/priorities-2019-2024/europe-fit-digital-age_en], Accessed 05 April 2021

2. Broadbent M., The Digital Services Act, the Digital Markets Act, and the New Competition Tool, Center for strategic and internarional studies, November 20 2021,p. 8, available at: [https://www.csis.org/analysis/digital-services-act-digital-markets-act-and-new-competition-tool], Accessed 30 April 2021

3. Cambridge dictionary, available at: [https://dictionary.cambridge.org/dictionary/english/ uberization], Accessed 08 April 2021

4. Digital Services Act - deepening the internal market and clarifying responsibilities for digital services, available on: [https://ec.europa.eu/info/law/better-regulation/have-your-say/ 
initiatives/12417-Digital-Services-Act-deepening-the-Internal-Market-and-clarifying-responsibilities-for-digital-services/public-consultation], Accessed 11 January 2021

5. Shaping Europe's digital future, POLICY, The Digital Services Act package, available at: [https://ec.europa.eu/digital-single-market/en/digital-services-act-package], Accessed 05 April 2021

6. The Digital Markets Act: ensuring fair and open digital markets, [https://ec.europa.eu/info/ strategy/priorities-2019-2024/europe-fit-digital-age/digital-markets-act-ensuring-fair-andopen-digital-markets_en], Accessed 05 April 2021

7. The Digital Services Act: ensuring a safe and accountable online, available at: [environmenthttps://ec.europa.eu/info/strategy/priorities-2019-2024/europe-fit-digital-age/digital-services-act-ensuring-safe-and-accountable-online-environment_sk], Accessed 30 April 2021

8. Vnútorný trh, Všeobecné zásady, available at: [https:/www.europarl.europa.eu/factsheets/ sk/sheet/33/vnutorny-trh-vseobecne-zasady], Accessed 07 April 2021 